\title{
Tüketim Eşitsizliği Profilinin Farklı Ürün Gruplarında İncelenmesi
}

\section{Investigating Consumption Inequality within Different Product Classifications}

\author{
Funda Bayrakdaroğlu ${ }^{\mathrm{a}^{*}}$, Hatice Hicret Özkoç ${ }^{\mathrm{b}}$ \\ a Dr. Öğr. Üyesi, Muğla Sttkı Koçman Üniversitesi, İktisadi ve İdari Bilimler Fakültesi, İşletme Bölümü, 48000, Muğla/Türkiye. \\ ORCID: 0000-0003-4460-0473
}

b Doçent Doktor, Muğla Sttkı Koçman Üniversitesi, İktisadi ve İdari Bilimler Fakültesi, İşletme Bölümü, 48000, Muğla/Türkiye.

ORCID: 0000-0003-0037-4603

\begin{tabular}{l} 
MAKALE BİLGİSI \\
Makale Geçmişi: \\
Başvuru tarihi: 30 Eylül 2020 \\
Düzeltme tarihi: 05 Kasım 2020 \\
Kabul tarihi: 11 Kasım 2020 \\
\hline Anahtar Kelimeler: \\
Tüketim \\
Tüketim Eşitsizliği \\
Ürün Sınıflandırması \\
Eşitsizlik Ölçümü \\
Hanehalkı Bütçe Anketi
\end{tabular}

ÖZ

Eşitsizliği ele alan çalışmaların odak noktasının çoğunlukla gelir eşitsizliği olduğu görülmektedir. Oysa, farklı tüketim kalemlerine yönelik harcamalar çerçevesinde ele alınan tüketim eşitsizliği de gelişmemiş ülkeler özelinde ampirik olarak incelemeye değer bir sorundur.

$\mathrm{Bu}$ çalışma, farklı ürün gruplarında tüketim eşitsizliğinin çeşitli sonuçlar ortaya çıkaracağını varsayarak kolayda, beğenmeli, özellikli ve aranmayan ürünlerden seçilen örnekler ile tüketim eşitsizliğini incelemektedir. TUİK tarafından gerçekleştirilen Hanehalkı Bütçe Araştırmasına dair veri seti kullanılarak tüketim eşitsizlikleri belirlenmiştir. Eşitsizliğin belirlenmesinde Eşdeğerlik Ölçeği, Gini Katsayısı, Genel Entropi ve Theil Endeksi kullanılmıştır. En çarpıcı sonuç; tüketim eşitsizliğinin özellikli ürünlerden mücevheratta en yüksek olmasıdır.

\section{ARTICLE INFO}

Article history:

Received 30 September 2020

Received in revised form 05 November 2020

Accepted 11 November 2020

\section{Keywords:}

Consumption

Consumption Inequality

Product Classification

Inequality Measurement

Household Budget Survey

\begin{abstract}
A B S T R A C T
It is seen that the focus of studies on inequality is mostly income inequality. However, consumption inequality, which can be handled within the framework of expenditures for different consumption items, is an empirically worthy problem for undeveloped countries.

This study examines consumption inequality with selected examples from convenience, shopping, specialty and unsought goods assuming that examining consumption inequality in different product groups will yield various results. For that purpose, data set of Household Budget Survey carried out by TURKSTAT was used in order to analyse consumption inequalities. Equivalence Scale, Gini Coefficient, General Entropy and Theil Index were performed to determine inequality. The most striking conclusion is that the consumption inequality is the highest in jewelery from the specialty products.
\end{abstract}

\section{Giriş}

Tüketim, insanoğlunun doğumuyla başlayıp ölümüne kadar durmadan devam eden en temel faaliyetleri arasında yer almaktadır. Her ne kadar tüketime yönelik ihtiyaç başlıkları (yeme-içme, barınma, güvenlik, sosyal ilişkiler vb.) evrensel gözükse de, bu ihtiyaçları tatmin etme alternatifleri ve söz konusu alternatiflere yapılan harcamalar tüketici grupları arasında oldukça büyük farklılıklar oluşturmakta, bu farklılıklar da "tüketimde eşitsizlik" olarak nitelendirilen ve çeşitli açılardan ele alınması gereken hem iktisadi hem de sosyolojik bir sorunu doğurmaktadır.

\footnotetext{
* Sorumlu yazar/Corresponding author.

e-posta: fkaya@mu.edu.tr
} 
Bununla birlikte, Fisunoğlu ve diğerlerine (2018) göre sosyal bilimlerin öne çıkan inceleme konularından olan eşitsizlik, özellikle az gelişmiş ve gelişmekte olan ülkelerin en önemli sorunlarından biri olarak da gözükmektedir. Çünkü ekonomik büyüme, istihdam, yoksulluk ve eşitsizlik arasındaki ilişki bir hayli karmaşık olup, aynı zamanda gelişmekte olan ülkelerde doğru politikalar kurgulama ve hılı ve sürdürülebilir bir ekonomik büyüme sağlama açısından bu ilişkiyi göz önünde bulundurmak gereklidir (Sarangi ve Panda, 2008).

Gelir, refah, eğitim, beceriler, firsatlar gibi alanların başı çektiği çok boyutlu eşitsizlik sorunu (Ayyash ve diğerleri, 2020), bir ülkenin politik, ekonomik ve sosyal politikalarının nihai sonuçlarından biri olması nedeniyle (Xia ve diğerleri, 2020), daha çok iktisat, maliye ve sosyoloji bilim dalları çerçevesinde ele alınmış olup, konuyu pazarlama ve tüketici davranışları perspektifinden inceleyen bir çalışmaya rastlanmamıştır. Oysa bireylerin tüketici olarak tercihleri ve bu tercihlerin ortaya koyduğu uçurumlar "eşitsizlik sorununun" pazarlama bilimi, spesifik olarak da tüketim, açısından önemini arttırmaktadır. Dahası, eşitsizlik üzerine yürütülen ampirik çalışmaların çoğunlukla gelir eşitsizliğine odaklandığı ancak tüketim eşitsizliğini göz ard1 ettikleri belirtilmektedir (Daşkaya ve Sağbaş, 2019). Dolayısıyla, gerek literatürdeki bu boşluk gerekse tüketim eşitsizliği konusunun artan önemi bu çalışmanın hazırlanmasına zemin hazırlamıştır.

Bireylerin, tüketim kalemlerine yönelik harcamaları şüphesiz bu kalemlerin tüketicilerin yaşamlarında dolduracağı boşluklar ya da bu ürünlere yüklenen anlamlar ile ilgilidir. Farklı bir ifadeyle, her tür ürün ya da hizmet tüketiciler için aynı derece vazgeçilmez olmadığı gibi, kırsal ve kentsel alanlardaki tüketicilerin ihtiyaç duyacağı ürün ve hizmetler arasında da büyük farklılıklar ortaya çıkacaktır. Ancak bu çalışmanın temel amacı, muhtemel kırsal ve kentsel eşitsizliklerden ziyade, pazarlama literatüründe oldukça geniş kabul görmüş ürün sınıfları (kolayda ürünler, beğenmeli ürünler, özellikli ürünler ve aranmayan ürünler şeklinde) ve her ürün grubundan seçilecek bir alt-bir üst sınır örneği üzerinden Türkiye'deki tüketim eşitsizliğini incelemek ve ortaya çıkacak eşitsizlikleri söz konusu ürün sınıfları bağlamında yorumlamaktır. Dolayısıyla çalışmanın bu amaç doğrultusunda araştırma sorusu "Ürün sınıfları çerçevesinde tüketim eşitsizliği nasıl farklılaşmaktadır?” şeklindedir. Bu araştırma sorusuna bağlı olarak alt araştırma sorusu ise "Her farklı ürün sınıfında yer alan örnek ürünlerin kendi içlerinde de tüketim eşitsizliğinden söz edilebilir mi?" şeklinde oluşturulmuştur. Çalışmanın ikincil bir amacı ise ürün sınıfları bağlamında ortaya çıkan tüketim eşitsizliklerinin gelir eşitsizliği ile ilişkisinin ortaya konmasıdır. Ürün sınıfları bağlamında tüketim eşitsizliklerinin ortaya konulması için bu çalışmada, literatürde eşitsizlik ölçümü için sıklıkla kullanılan yöntemlerden Gini Katsayısı ve Theil Endeksinden yararlanılmıştır. Türkiye İstatistik Kurumu (TUİK) tarafindan 2018 Hanehalkı Bütçe Anketinden elde edilen verilerden yola çıkarak gerçekleştirilen eşitsizlik ölçümlerinde aynı zamanda Eşdeğerlik Ölçeği dikkate alınmış olup, Genel Entropi yardımıyla da ölçek hesaplamaları yapılmıştır.

\section{Literatür Taraması}

Özellikle kapitalist sistemlerin vazgeçilmezi olan tüketim, hiçbir otorite tarafından sınırlandırılmadığı için belki de insanoğlunun en özgür olabildiği alanlarından biridir (Kaymak ve Babacan, 2020). Bireylerin herhangi bir kısıtlamaya maruz kalmadan devam ettirdikleri tüketim hayatları birtakım eşitsizleri de beraberinde getirmektedir. Tüketim eşitsizliği dünyada birçok ülke özelinde araştırmaya konu olmuştur (Xia ve diğerleri, 2020). Ayyash ve diğerleri (2020), 2017 y1lı Filistin Hanehalkı Harcama ve Tüketim Araştırmasından elde ettikleri veriler üzerinden yürüttükleri çalışma sonucunda, özellikle yaşanılan bölge, eğitim ve çalışma durumu gibi hanehalkı özelliklerinin düzeltilmiş tüketim eşitsizliğinin açıklanmasında en önemli faktörler olduğunu belirtmektedir. Zhang ve diğerleri (2020) ise tüketim eşitsizliği sorununun bilgi teknolojileri bağlamında yeterince irdelenmediği tespitinden yola çıkarak 2010-2016 yıllarına ilişkin 155 ülke verisiyle Gini katsayısı ile ölçüm yapmış ve Internet penetrasyonunun tüketim eşitsizliği üzerinde pozitif etkisi olduğu sonucuna ulaşmıştır. Blundell ve Etheridge de (2009), İngiltere özelinde gelir ve tüketim eşitsizliklerinin seyrini 1978 yılından bu yana analiz etmişler, tüketim eşitsizliğinin 1980'li yılların başında çok arttığı, bu artışın 1990'lı yıllarda daha az bir seviyede artmaya devam ettiği bulgusuna ulaşmışlardır. Idrees ve Ahmad (2010) ise Pakistan'da tüketim harcamalarındaki eşitsizliğin 19921993 ve 2004-2005 arasında artış gösterdiğini, gıda tüketimindeki eşitsizliğin gıda-dışı eşitsizliğe göre önemli düzeyde düşük olduğunu ve hanehalkının eğitim harcamalarında eşitsizlik seviyesinin diğer harcamalara kıyasla çok yüksek gerçekleştiğini ortaya koymuştur. Basole ve Basu da (2015)- farklı din, kast, ekonomik ve sosyal gruplardan oluşan Hindistan'da (Sarangi ve Panda, 2008)- reform sonrası dönem için hanehalkı bütçesinde gıda-dışı grupların payının artmasına bağlı olarak tüketim eşitsizliğinin arttığı, ancak gıda-dışı eşitsizliğin azaldığı sonucuna ulaşmışlardır. Polonya'da 1989-1990 yıllarındaki ekonomik dönüşümün sonrasında tüketim ve gelir eşitsizliklerinin incelendiği çalışmada, dönüşümün hemen ardından gelir eşitsizliğinin arttığı fakat ilerleyen dönemlerde ise ekonomik dönüşümün bile altına indiği sonucuna ulaşılmıştır. Yine aynı çalışmada, tüketim eşitsizliğinin de gelir eşitsizliğine benzer bir değişim içerisinde olduğu belirtilmektedir (Keane ve Prasad, 1999).

Yabancı literatürde tüketim eşitsizliğinin araştırmalara sıkça konu olmasına karşın, kavrama ilişkin yerli literatür oldukça sınırlıdır (Daşkaya ve Sağbaş, 2019). Türkiye'deki ücret, gelir ve tüketim eşitsizliklerindeki değişimi TÜİK Hanehalkı Bütçe Araştırması ve Gelir ve Yaşam Koşulları Araştırmasına dayanarak 2002-2016 yıllarına ilişkin inceleyen Tamkoç ve Torul (2020), söz konusu eşitsizliklerin ilgili dönemde aşağı yönlü olduğunu belirtmektedir. Bununla birlikte, yine TÜİK'in 2003-2014 yıllarına yönelik Hanehalkı Bütçe Anketi verileri üzerinden Gini katsayısını ve Atkinson endeksini kullanarak ampirik bir araştırma yürüten Daşkaya ve Sağbaş (2019), 20122014 yılları arasındaki eşitsizliğin ele aldıkları tüm dönem ortalamasının altında kaldığı, yaş grubu azaldıkça ise tüketim eşitsizliğinin de azaldığı sonucunu elde etmişlerdir. Benzer şekilde, gelir ve tüketim eşitsizliğinin farklı yaş grupları bağlamında değişkenlik gösterebileceği öngörüsüyle OECD ülkelerine ilişkin yürütülen çalışmada 
elde edilen sonuca göre nüfustaki yaşlanma hem gelir hem de tüketim eşitsizliğini arttırmaktadır (Fisunoğlu ve diğerleri, 2018). Duygan ve Güner (2006) ise 1994-2002 yıllarına ilişkin Hanehalkı Gelir ve Tüketim Harcamaları Araştırmasından faydalanarak eğitimin gelir ve tüketim eşitsizlikleri üzerindeki rolünü tartışmıştır.

Eşitsizlik konusundaki çalışmaların tüketim eşitsizliği yerine, daha çok gelir eşitsizliğini ele alması dikkati çekmektedir. Fisunoğlu ve diğerlerine (2018) göre bu durum gelir eşitsizliğinin tüketim eşitsizliğine kıyasla nispi olarak ölçümünün daha elverişli olmasından kaynaklanmaktadır. Bir diğer görüşe göre literatürdeki bu yoğunlaşmanın temel sebebi, tüketim eşitsizliğinin gelir eşitsizliğini takip edeceği ancak ondan daha az olacağ beklentisidir. Başka bir ifadeyle, gelir seviyeleri birbirinden oldukça farklı olan iki hanehalkının tüketim anlamında birbirlerinden çok da uzak olamayacağı kabul edilmektedir. Örneğin gelirleri arasında 10 kat olan iki hanehalkının, zorunlu ihtiyaçlardan biri olan ekmek tüketimleri arasında fizyolojik sınır sebebiyle 10 kat fark oluşamayacaktır (Daşkaya ve Sağbaş, 2019). Bu durum ekmek gibi zorunlu tüketim malları için oldukça gerçekçi ve genelleyici olsa da, diğer tüketim malları açısından incelenmeye değer hipotezler ortaya koymaktadır. Örneğin Idrees ve Ahmad (2010) tüketim harcamalarını Pakistan bağlamında inceledikleri çalışmalarında gıda tüketimindeki eşitsizliğin, gıda dışı tüketimdeki eşitsizliğe kıyasla önemli ölçüde düşük olduğu sonucuna ulaşmışlardır.

Eşitsizliğin incelenmesinde gelire kıyasla daha ilgi çekici bir kavram olarak görülen tüketim (Keane ve Prasad, 1999), bireylerin yaşamları hakkında çok önemli ipuçları sunmaktadır. $\mathrm{Bu}$ görüşe göre, bireylerin tüketim davranışlarını incelemek ve buna ilişkin öneriler ortaya koymak ekonomik kalkınmaya hizmet edeceği gibi, eşitsizliklerin azaltılması yönünde de rol oynayacaktır (Sarangi ve Panda, 2008). Bugünün tüketim dünyası bireyleri çoğunlukla rasyonel gerekçelerle satın alınan ürün ve hizmetlerden çok öteye taşımakta, postmodern olarak nitelendirilen tüketiciler duygusal motivasyonlarla da hareket ederek tüketim kararları almaktadırlar. Başka bir ifadeyle, 21. yüzyılda tüketicilerin ihtiyaçları arasında oldukça büyük farklar dikkati çekmektedir. Örneğin karnı aç insanın yemeğe olan ihtiyacı ile daha güzel ve şık gözükmek isteyen bir kadının pahalı ya da gösterişli kıyafetlere olan ihtiyacı doğal olarak birtakım eşitsizlikleri ortaya çıkaracaktır (Torlak, 2016). Tüketimi ölçmek ya da birçok faktör bağlamında neyin tüketim olarak kabul edileceğini belirlemek oldukça karmaşık ve zor olsa da (Daşkaya ve Sağbaş, 2019), özellikle az gelişmiş ülkelerde, gelire kıyasla tüketimin refahın daha doğru bir göstergesi olması tüketim eşitsizliğinin yiyecek, barınma ve sağlık gibi tüketim kalemleri çerçevesinde incelenmesini haklı k1lmaktadır (Idrees ve Ahmad, 2010). Basole ve Basu da (2015) ise gıda ve gıda-dışı ürün kategorileri arasındaki eşitsizliğin çok farklı olabileceğine, bu nedenle, bu kategorileri kıyaslayan çalışmaların önemine dikkati çekmektedir. Dolayısıyla, ürün sınıflandırmaları bağlamında ortaya çıkacak eşitsizlik farklılıkları incelenmeye ve yorumlanmaya değer gözükmektedir.

Pazarlama literatüründe ürünler satın alınma sıklıklarına göre kolayda, beğenmeli, özellikli ve aranmayan ürünler şeklinde sınıflandırılmaktadır (Lancaster ve Reynolds,
2005). Tüketim ürünlerinin sınıflandırılmasında her ne kadar farklı kriterler kullanılsa da, bu sınıflandırma ilgili literatürde en kullanışlı ayrım olarak değerlendirilmektedir (Lamb ve diğerleri, 2009). Bu sınıflandırmaya göre kolayda ürünler, tüketiciler tarafindan günün herhangi bir saatinde herhangi bir yerden kolaylıkla satın alınabilen ve çoğunlukla hızlı tüketim malları olarak nitelendirilen ekmek, süt, tuvalet kağıdı, pil ve çay gibi ürünlerden oluşmaktadır (Wright, 1999). Bu ürünler diğer ürün kategorilerine kıyasla daha ucuza, bu nedenle de tüketiciler tarafından daha az çaba harcanarak satın alınırlar. Ayrıca, kolayda ürünler, kendi arasında hemen hemen her gün tüketilen temel kolayda ürünler ve önceden hazırlık yapmadan dürtüsel olarak satın alınan kolayda ürünler olmak üzere ikiye ayrılmaktadır (Lancaster ve Reynolds, 2005). Kavak ve Sığındı'ya (2012) göre kolayda ürünler; sıradan (rutin) ürünler, dürtüsel (iç tepkisel) ürünler ve acil ürünler olarak gruplandırılabilmektedir.

Beğenmeli ürünler ise tüketicilerin seçim yapmak için süreye ihtiyaç duyacağı, satın alım kararı vermek içinse farklı satış noktalarına uğramak ve kıyaslamak isteyeceği ürünlerden oluşmaktadır. Mobilya, otomobiller, her türlü beyaz eşya ve tatiller bu ürün sınıflandırmasına örnektir (Wright, 1999). Kolayda ürünler gibi beğenmeli ürünler de kendi arasında iki alt kategoriye ayrılmaktadır: Dayanıklı ve yarı-dayanıklı ürünler. Bu ayrıma ek olarak, beğenmeli ürünler homojen ve heterojen olarak da gruplandırılmaktadır (Lancaster ve Reynolds, 2005). Buna göre, tüketiciler homojen beğenmeli ürünleri birbirine benzer algıladıkları için elde etmek istedikleri faydayı sunan "en uygun fiyatlı" ürüne yönelmektedirler. Fakat mobilya gibi heterojen beğenmeli ürünler için tam tersine birtakım farklılıklar algılamaları nedeniyle fiyat, kalite ya da özellikler bakımından kıyaslama yapmaya ihtiyaç duyarlar (Lamb ve diğerleri, 2009).

Çoğu tüketicilerin kendi imajları ile örtüşen anlam taşıyan özellikli ürünler, tüketicilere üst düzeyde ve farklı faydalar sağladığı için bu ürünlere karşı yüksek sadakat gösterilebilir (Kavak ve Sığındı, 2012). Bundan dolayı, tüketiciler özellikli ürünler için kapsamlı bir araştırma yapmak isterler ve genelde bu ürünlerin ikamelerini kabul etmezler. Pahalı saatler ya da otomobiller özellikli ürünlerin örnekleri arasındadır. $\mathrm{Bu}$ özellikleri nedeniyle, pazarlamacılar özellikli ürünlerin seçkin imajlarını öne çıkarmak adına sınırlı dağıtım ve statüyü öne çıkaran iletişim stratejilerinden faydalanırlar (Lamb ve diğerleri, 2009). Lüks ürünler olarak da ifade edilen bu grupta mücevher gibi ürünler de yer almaktadır (Kotler, 2003).

Kavak ve Sığındı'ya (2012) göre, pazarlama literatüründe 1990'l1 yıllardan itibaren incelenmeye başlanan aranmayan ürünler tüketicilerin varlığından haberdar olmadıkları ya da olsalar bile kendiliklerinden satın almaya yönelmedikleri ürünlerden oluşmaktadır. Başka bir ifadeyle, aranmayan ürünlere ihtiyaç duyulmakla birlikte, aktif olarak satın alınmazlar. Aranmayan ürünlerin en yaygın örnekleri çeşitli sigorta türleri, cenaze hizmetleri ya da uzatılmış garantilerdir. Dahası, bu tür ürünleri pazarlamak için satıcıların müşterileri bulmak ve ikna etmek anlamında ekstra çaba göstermeleri gerekmektedir (Wright, 1999). Diğer ürün sınıflandırmalarında olduğu gibi aranmayan ürünler de iki grupta incelenebilir: Mevcut ve yeni aranmayan ürünler. Mevcut aranmayan ürünlere örnek 
mezar taşı gösterilirken, yeni aranmayan ürünlere ise hayat sigortası örnek verilebilir (Kavak ve Sığındı, 2012).
Kolayda, beğenmeli, özellikli ve aranmayan ürünlere ilişkin karşılaştırmalar Tablo 1'de sunulmaktadır.

Tablo 1. Ürün Sınıflarının Farklı Kriterler Bağlamında Karşılaştırılması

\begin{tabular}{|c|c|c|c|c|}
\hline & Kolayda & Beğenmeli & Özellikli & Aranmayan \\
\hline Harcanan çaba & Düşük & Yüksek & Çok yüksek & Çok düşük \\
\hline Algılanan risk & Düşük & Yüksek & Çok yüksek & Düşük \\
\hline Fiyat- kalite karşılaştırması & Yapilmıyor & Yapıliyor & Yapılmiyor & Değişken \\
\hline Algılanan fiyat düzeyi & Düşük & Yüksek & Çok yüksek & Değişken \\
\hline Satın alım sıklığı & Genelde yüksek & Orta düzeyde & Seyrek & Seyrek \\
\hline Satın alma karar türü & Rutin veya otomatik & Sinırlı & Kapsamlı & Sinırlı \\
\hline İlgilenim düzeyi & Düşük & Orta düzeyde & Yüksek & Çok düşük \\
\hline Marka sadakati & $\begin{array}{l}\text { Markanın farkında ancak } \\
\text { alternatif kabul ediliyor. }\end{array}$ & $\begin{array}{l}\text { Belirli markalar tercih } \\
\text { ediliyor, ancak alternatif } \\
\text { de kabul ediliyor. }\end{array}$ & $\begin{array}{l}\text { Markaya sadık, } \\
\text { alternatif kabul } \\
\text { edilmiyor. }\end{array}$ & $\begin{array}{l}\text { Markanın farkında } \\
\text { olunmaz, } \\
\text { markaya sadakat } \\
\text { yoktur. }\end{array}$ \\
\hline
\end{tabular}

Kaynak: Kavak ve Sığındı, 2012:54'ten uyarlanmıştır.

Tablo 1'e göre ürün sınıflarına ilişkin tüketim karar kriterlerinin birbirlerinden oldukça farklılık gösteriyor olması tüketim eşitsizliğinin bu bağlamda incelenmesinin önemini ortaya koymaktadır. Her ne kadar literatürde tüketim eşitsizliğini farklı perspektiflerden ele alan çalışmalar bulunsa da, tüm ürün sınıflamalarını kapsayan bir çalışmaya rastlanmamıştır.

\section{Metodoloji}

Eşitsizliğin nedenlerini ve sonuçlarını anlamak ve zaman içindeki gelişimini izlemek için, eşitsizliğin şeffaf bir tanımı ve ölçümü bir ön koşuldur. Buna karşın eşitsizliğin nasıl tanımlanması ve ölçülmesi gerektiği sorusunun henüz net bir cevabı yoktur. En yaygın kullanılan eşitsizlik ölçütlerine bakıldığında örtük etik varsayımlar üzerine inşa edildikleri ortaya çıkmaktadır. Her ne kadar üzerinde uzlaşılan net bir ölçütü olmamasına karşın, özellikle gelir eşitsizliğinin ölçülmesi ihtiyacı nedeniyle, çeşitli yöntemler yardımıyla eşitsizliğin ölçülmesine çalışılmaktadır. Geliştirilen ve literatürde kullanılan eşitsizlik ölçüm yöntemleri genel olarak objektif ölçütler, normatif ölçütler ve statik ölçüt olmak üzere üç başlık altında toplanmaktadır (Orhan ve Demir, 2019). Statik ölçüt, normatif yöntemler ile hesap edilen sonuçları grafiksel bir gösterim ile sunan Lorenz eğrisi olup, özellikle nüfus ve gelir dağılımı değişkenlerinin birleşimini göstermektedir. Normatif ölçütler sosyal refah anlayışını da hesaba katan ölçütlerdir. Dalton Ölçütü, Atkinson Eşitsizlik Endeksi, mutlak eşitsizlik endeksleri ve göreceli eşitsizlik endeksleri normatif ölçütler altında yer alan eşitsizlik ölçütleridir (Blackorby ve diğerleri, 2001). Objektif ölçütler ise istatistiki ölçüm yöntemleri olup kendi içerisinde merkezi eğilim ve değişkenlik ölçütlerine dayananlar ile özellikli ölçüm yöntemleri olmak üzere iki ana başlık altında toplanmaktadır (Özdemir, 2019). Aritmetik ve geometrik ortalama, varyans, standart sapma ve değişim katsayısı merkezi eğilim ve değişkenlik ölçütleri olup bunlar yardımıyla eşitsizliğin ölçümü ve karşılaştırması mümkün olmakla beraber literatürde daha sıklıkla özellikli ölçüm yöntemlerinin tercih edildiği görülmektedir.

Özellikli ölçüm yöntemleri; içerisinde pek çok yöntemi barındırmakla birlikte, en çok bilinenleri Gini Katsayısı, Genel Entropi ve Theil Endeksi, Kuznets Ters U Eğrisi ve Eşdeğerlik Ölçeğidir. Bunların dışında Yüzde Paylar Analizi, Pareto Optimumu Katsayısı ve Jan Pen Geçit Töreni özellikli ölçüm yöntemleri içerisinde yer alan diğer ölçütlerdir (Özdemir, 2019).

$\mathrm{Bu}$ çalışmada tüketim eşitsizliği objektif ölçütlerden özellikli ölçüm yöntemleri arasında yer alan Eşdeğerlik Ölçeği, Gini Katsayısı, Genel Entropi ve Theil Endeksi yardımıyla incelenmektedir. Söz konusu yöntemlerin tercih edilmesinin temel nedeni, eşitsizlik ölçümlerinde bu yöntemlere literatürde sıklıkla başvuruluyor ve yaygın kabul görüyor olmasıdır. Başlangıçta ekonomik refahtaki eşitsizliği ölçmek için geliştirilen bu endeksler enerji (Jacobson ve diğerleri, 2005), ekolojik hizmetler/kaynaklar (Chen ve diğerleri, 2010), sağlık (Theodorakis ve diğerleri, 2006) ve su kullanımı (Malakar ve Mishra, 2017) gibi alanlarda da eşitsizliklerin belirlenmesi için kullanılmaktadir.

\subsection{Eşdeğerlik Ölçeği}

Temeli tüketici kuramına dayanan eşdeğerlik ölçekleri, hanehalkında yer alan bireylerin yaşları dikkate alınarak hanehalkının toplamda kaç yetişkine denk geldiğinin hesaplanması için kullanılan bir yöntemdir (Öztornacı ve Demirdöğen, 2015). Bilhassa, tüketim ihtiyacının farklı yaş gruplarında farklı şekillerde yoğunluk göstermesi nedeniyle gelirin gerçekte kaç yetişkin tarafindan paylaşıldığını ölçmeye yarayan bir ölçektir (Özdemir, 2019: 38). Yenilenmiş OECD ölçeğine göre eşdeğer hanehalkı büyüklüğü, hanedeki ilk yetişkin için 1, 14 ve daha yukarı yaştaki fertler için $0.5,14$ yaşından küçük fertler için 0.3 değerleri dikkate alınarak hesaplanan hanehalkı büyüklüğüdür ve TÜİK tarafından da kullanılmaktadır. 


\subsection{Gini Katsayıs1}

Lorenz eğrisi yardımıyla hesaplanan Gini katsayısı $[0,1]$ kapalı aralı̆̆ında değer alan bir katsayıdır. 0 değeri eşitsizliğin olmadığ mükemmel eşitliğin gerçekleştiği durumu ifade ederken 1 ise mükemmel eşitsizliğe karşllı gelmektedir (Todaro ve Smith, 2015). Bu nedenle, katsayının 0'a yaklaşması arzu edilen bir durumdur. Katsayının matematiksel gösterimi şu şekildedir (Huber ve diğerleri, 1994):

$$
G=\frac{1}{2 \mu n^{2}} \sum_{j=1}^{m} \sum_{k=1}^{m} n_{j} n_{k}\left|y_{j}-y_{k}\right|
$$

Burada $\mu$ ortalama geliri, y_jve $y_{-} k$ sirasiyla $j$. ve $k$. grubun gelirini göstermektedir. Lorenz eğrisi yardımıyla da hesaplanabilen Gini Katsayısı, Lorenz eğrisi ile tam eşitlik doğrusu arasında kalan alanın tam eşitlik doğrusu altında kalan alana bölünmesi yardımıyla da hesaplanabilmektedir.

\subsection{Genel Entropi ve Theil Endeksi}

Çoğunlukla ülkelerin ve bölgelerin gelir dağıllımları karşılaştırılırken kullanılan Theil Endeksi yeterli büyüklükte veri olmasa bile sağlıklı sonuçlar vermektedir. Entropi kavramından türetilen bu endeks hem bireysel hem de gruplar arası verilerin eşitsizliğini ölçebilmektedir. Bireysel verilerin kullanıldığı durumlarda endeks aşağıda verilen eşitlik yardımıyla hesaplanmaktadır (Chakravarty ve Eichhorn, 1994):

$$
T=\frac{1}{n} \sum_{i}\left(\frac{y_{i}}{\bar{y}}\right) \ln \left(\frac{y_{i}}{\bar{y}}\right)
$$

Theil endeksi sıfir ile sonsuz arasında bir değer alan bir endeks olup, değer küçüldükçe eşitsizliğin azaldığı büyüdükçe ise arttığı anlamına gelmektedir. Endeks, bireylerin gelirlerini diğer bireylerin gelirleriyle karşılaştırmak yerine, nüfusun ortalama geliri ile karşllaştırmaktadır (Uysal ve Vatansever Deviren, 2016).

Bu çalışmada, eşdeğer hanehalkı büyüklükleri göz önüne alınarak hem Gini Katsayısı hem de Theil Endeksi farklı ürün sınıflamalarından ikişer tüketim malı belirlenerek bunlara hanehalkının yaptığ harcamalar bağlamında hesaplanmıştır.

\section{Veri}

Bu çalışmada TÜIK'in 2018 y1lı Hanehalkı Bütçe Araştırması mikro veri seti kullanılmıştır. ${ }^{1}$ TÜIK bu anket araştırmasında hanehalkının sosyo-ekonomik durumunu, fertlerin istihdam durumunu, fertlerin elde ettikleri yıllık gelirler ile hanehalkının bir ay boyunca alt gruplar bazında yaptığı harcamaları toplamıştır. 1 Ocak - 31 Aralık 2018 döneminde toplam 11.828 hanehalkı ile görüşülmüş olup kullanılan örnekleme tasarımı sayesinde 2018 Hanehalkı Bütçe Anketinin tahmin düzeyi Türkiye genelidir. Hanehalklarından görüşme, kayıt ve gözlem yardımıyla veriler derlenmiş olup anket ayı öncesinde hanehalkları ile görüşülerek harcama kayıt defterinin nasıl doldurulacağ 1

\footnotetext{
${ }^{1}$ Türkiye İstatistik Kurumu Başkanlığı Bilgi Dağıtım ve İletişim Daire Başkanlığı'nın 27964695-622.03-E.27190 sayılı yazısı ve izni uyarınca Hanehalkı Bütçe Araştırmas 2018 yılı mikro veri setine erişim sağlanmıştır.
}

açıklanmıştır. 1 ay boyunca hanenin gıda, giyim, ulaşım, sağlık, eğitim ve kültür gibi alt gruplar bazında toplam 280 kalem üzerinde gerçekleş̧irdiği tüketim harcamaları hanehalkına bırakılan kayıt defterinden kayıtlama ve görüşme yöntemleri ile elde edilmiştir.

Tüketim eşitsizliğinin araştırılmaya çalışıldığ çalışmada, ele alınan tüketim maddelerinin satın alış biçimindeki elde edilişleri ve bu elde ediş için gerçekleştirdikleri harcama değerleri dikkate alınmıştır. Hanehalkının kendi üretimi, ayni gelir niteliğindeki mal ve hizmet değeri, işyerinden haneye getirdiği ürünler ile hediye veya yardımlar çalışmada kapsam dışında bırakılmıştır. Böylece doğrudan hanehalkının gerçekleştirdiği tüketim harcamaları ve bu harcamalar arasındaki eşitsizlikler irdelenmeye çalışılmıştır. Aynı zamanda genel eşitsizlik durumu göstermek ve kıyaslama yapabilmek için hanehalkı yıllık kullanılabilir geliri ile aylık harcama tutarları bağlamında da eşitsizlik durumları incelenmiştir. Hanehalkının aylık harcama tutarı, alt gruplar bazında gerçekleştirdiği tüketim tutarlarının toplamı olarak ele alınmış olup kullanılabilir yıllık gelir ise ayni ve nakdi tüm gelirleri içermektedir.

Araştırmanın amacına uygun olarak kolayda, beğenmeli, özellikli ve aranmayan ürün gruplarından ikişer örnek seçilmiştir. Söz konusu ürün örneklerine karar verirken öncelik, bu örneklerin literatür taramasında verilen açıklamalardaki özellikleri taşımaları olmuştur. Ardından, her ürün sınıflandırmasından iki örnek olmasına karar verilmiştir. Bunun temel nedeni ise, tek bir ürün örneği üzerinden yapılan incelemenin hatalı bir yaklaşım olacağ 1 ve eksik sonuç verebileceği endişesidir. $\mathrm{Bu}$ nedenle, kolayda ürünleri temsilen yumurta ve çay, beğenmeli ürünleri temsilen giyim ve ev mobilyası, özellikli ürünler için yeni motorlu araçlar ve mücevherat, son olarak aranmayan ürünlerden özel sağlık sigortası ve cenaze hizmetleri örnek olarak seçilmiştir. Bununla birlikte, her gruptan seçilen örnek ürünlerin ait oldukları sınıflandırmanın zıt uçlarda olmasına dikkat edilmiştir. $\mathrm{Bu}$ kriteri kolayda ürünler için sağlamak zor olsa da, beğenmeli, özellikli ve aranmayan ürün sınıflandırmaları için alt ve üst örnekleri seçmek mümkün olmuştur.

Tablo 2, hanelerin gelir ve harcama miktarlarına ilişkin betimsel istatistikleri içermektedir. Gelir ve aylık harcama tüm haneler için elde edilmiş olup ürünlere ilişsin harcamalar ise anket ayı içerisinde söz konusu ürünü alan haneler bağlamında elde edilmiştir. Bu nedenle örneklem büyüklükleri ürün gruplarında farklılaşmaktadır. 
Tablo 2. Betimsel İstatistikler

\begin{tabular}{lllllll}
\hline & $\mathrm{n}$ & Min. & Mak. & Ortalama & Ortanca & Std.Sapma \\
\hline $\begin{array}{l}\text { Y1llık } \\
\text { Kullanılabilir Gelir }\end{array}$ & 11828 & 1879.73 & 1552820.78 & 56786.83 & 44809.78 & 55042.70 \\
\hline Aylık Harcama & 11828 & 109 & 81795.47 & 4206.19 & 3233.82 & 3668.04 \\
\hline $\begin{array}{l}\text { Yumurta } \\
\text { Harcamas1 }\end{array}$ & 9115 & 1 & 217.95 & 27.91 & 23.5 & 19.53 \\
\hline Çay Harcamas1 & 7683 & 1.25 & 590 & 35.15 & 26 & 28.49 \\
\hline $\begin{array}{l}\text { Giyim Malzemeleri } \\
\text { Harcamas1 }\end{array}$ & 171 & 5 & 400 & 57.50 & 35 & 65.78 \\
\hline $\begin{array}{l}\text { Ev Mobilyas1 } \\
\text { Harcamas1 }\end{array}$ & 2990 & 0.13 & 10843.3 & 263.98 & 134.33 & 420.75 \\
\hline $\begin{array}{l}\text { Yeni Motorlu } \\
\text { Araçlar Harcamas1 }\end{array}$ & 141 & 2649.88 & 21666.67 & 9005.56 & 7895.56 & 3712.59 \\
\hline $\begin{array}{l}\text { Mücevherat } \\
\text { Harcamas1 }\end{array}$ & 508 & 1 & 70000 & 605.62 & 20 & 3953.35 \\
\hline $\begin{array}{l}\text { Özel Sağlık } \\
\text { Sigortas1 }\end{array}$ & 30 & 45 & 2500 & 493.34 & 342 & 546.59 \\
\hline Cenaze Hizmetleri & 18 & 20 & 3000 & 880 & 550 & 860.72 \\
\hline $\begin{array}{l}\text { Hanehalk1 } \\
\text { Büyüklüğ̈̈ }\end{array}$ & 11828 & 1 & 16 & 3.44 & 3 & 1.75 \\
\hline
\end{tabular}

\section{Bulgular}

TÜIKK tarafından gerçekleştirilen 2018 Hanehalkı Bütçe Anketi verilerine dayanarak tüketici eşitsizliğinin incelendiği bu çalışmada öncelikle hanelerin kullanılabilir gelirlerine ilişkin eşitsizlik ölçütleri hesaplanmıştır. 2018 yılına dair TÜiK tarafindan açıklanan eşdeğer hanehalkı kullanılabilir fert gelirine göre Gini Katsayısı 0.408'dir. Bu çalışmada Hanehalkı Bütçe Anketi mikro verileri yardımıyla hesaplanan yıllık kullanılabilir gelire ilişkin Gini Katsayısı ise 0.366 olarak bulunmuştur. Söz konusu iki değerin birbirine oldukça yakın olması ankette kullanılan örneklemin Türkiye genelini temsil etme düzeyindeki başarısını göstermektedir. $\mathrm{Bu}$ noktadan hareketle, tüketime ilişkin harcama üzerinden elde edilecek eşitsizlik değerlerinin de ülke genelini temsil edecek düzeyde olduğu düşünülmektedir.

Excel yardımıyla gerçekleştirilen hesaplamalar neticesinde elde edilen eşitsizlik ölçütleri Tablo 3 ile verilmektedir. Hanelerin yıllık kullanılabilir gelirleri açısından hesaplanan Gini Katsayısı 0.366 iken aylık harcama tutarının Gini Katsayısı ise 0.373 olarak bulunmuştur. Toplam gelir ve toplam harcama açısından katsayının birbirine oldukça yakın olmasına karşın, ürün sınıflarından sadece kolayda malların benzer Gini Katsayılarına sahip olduğu görülmektedir. En yüksek Gini Katsayısının görüldügüü ürün grubu ise özellikli mallardan mücevherat harcamalarıdır. Bir diğer yüksek katsayıya sahip ürün grubu ise beğenmeli mallar içerisinde ev mobilyası harcamalarıdır. Aranmayan mallar da benzer şekilde Gini Katsayısı yüksek ürün grupları olarak ortaya çıkmıştır. Gini Katsayısının sıfıra en yakın olduğu ürün grubu ise yeni motorlu araç harcamalarıdır.

Theil Endeksi açısından bakıldığında Gini Katsayısına benzer şekilde kullanılabilir gelir ile harcama tutarlarının eşitsizlik düzeyleri birbirine oldukça benzer bulunmuştur. Kolayda mallar ürün grubunda yer alan alt kalemlere ilişkin endeks değerleri de yine gelir ve harcamaya ilişkin değerlere yakın çıkmıştır. Theil Endeksine göre tüketim eșitsizliğinin en yüksek olduğu ürün grubu yine Gini Katsayısında olduğu gibi mücevherat harcaması olmuştur. En düşük Theil Endeksi ise yine Gini Katsayısında elde edilen sonuçlara paralel olarak yeni motorlu araç harcamalarında görülmüștür. Ev mobilyasına yapılan harcamaların eşitsizlik düzeyleri ise Theil Endeksi göz önüne alındığında diğer ürün gruplarına kıyasla oldukça fazla çıkmıştır. Özel sağlık sigortası, cenaze hizmetleri ile giyim malzemeleri harcamalarında ise benzer bir eşitsizlik durumunun mevcut olduğu görülmektedir.

Tablo 3. Eşitsizlik Ölçütleri

\begin{tabular}{|c|c|c|c|c|c|c|c|}
\hline & & $\begin{array}{l}\text { Gini } \\
\text { KatsayısI }\end{array}$ & $\begin{array}{l}\text { Theil } \\
\text { Endeksi }\end{array}$ & & & $\begin{array}{l}\text { Gini } \\
\text { Katsayısı }\end{array}$ & $\begin{array}{l}\text { Theil } \\
\text { Endeksi }\end{array}$ \\
\hline Y1llık Kulla & labilir Gelir & 0.366 & 0.262 & Aylık Harca & & 0.373 & 0.255 \\
\hline \multirow{2}{*}{$\begin{array}{l}\text { Kolayda } \\
\text { Ürünler }\end{array}$} & $\begin{array}{l}\text { Yumurta } \\
\text { Harcamas1 }\end{array}$ & 0.361 & 0.214 & \multirow{2}{*}{$\begin{array}{l}\text { Özellikli } \\
\text { Ürünler }\end{array}$} & $\begin{array}{l}\text { Yeni Motorlu } \\
\text { Araçlar } \\
\text { Harcaması }\end{array}$ & 0.218 & 0.077 \\
\hline & $\begin{array}{l}\text { Çay } \\
\text { Harcamas1 }\end{array}$ & 0.361 & 0.234 & & $\begin{array}{l}\text { Mücevherat } \\
\text { Harcamas1 }\end{array}$ & 0.935 & 2.864 \\
\hline \multirow{2}{*}{$\begin{array}{l}\text { Beğenmeli } \\
\text { Ürünler }\end{array}$} & $\begin{array}{l}\text { Giyim } \\
\text { Malzemeleri } \\
\text { Harcamas1 }\end{array}$ & 0.492 & 0.438 & \multirow{2}{*}{$\begin{array}{l}\text { Aranmayan } \\
\text { Ürünler }\end{array}$} & $\begin{array}{l}\text { Özel Sağlık } \\
\text { Sigortas1 }\end{array}$ & 0.488 & 0.431 \\
\hline & $\begin{array}{l}\text { Ev Mobilyas1 } \\
\text { Harcamas1 }\end{array}$ & 0.616 & 0.708 & & $\begin{array}{l}\text { Cenaze } \\
\text { Hizmetleri }\end{array}$ & 0.495 & 0.409 \\
\hline
\end{tabular}


Şekil 1, Tablo 3 ile verilen değerlerin dağılımlarının daha açık bir biçimde görülmesi amaciyla oluşturulmuştur. Her iki eşitsizlik ölçütü göz önüne alındığında çoğunlukla benzer bir davranış sergilendiği görülmektedir. Aynı zamanda yeni motorlu araç harcamalarının eşitsizliğin en düşük olduğu harcama grubu olduğu buna karşın mücevherat harcamaların da ise eşitsizliğin en yüksek düzeyde çıktığg Şekil 1'de görülmektedir.

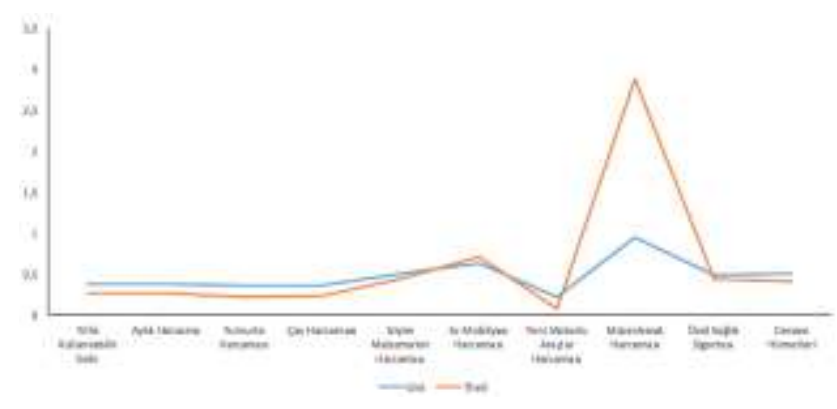

Şekil 1. Eşitsizlik Değerleri

\section{Sonuç ve Öneriler}

Hemen her alanda önemli bir sorun ortaya koyan eşitsizlik konusu, tüketim ve tüketici davranışları çerçevesinde ele alındığında sosyal ve ekonomik problemlerin ve hatta uçurumların oluşmasına zemin hazırlayabilmektedir. Literatürdeki gelir eşitsizliği odaklı çalışmaların aksine, bu çalışma tüketim eşitsizliğine odaklanarak tüketim tercihlerindeki muhtemel eşitsizlikleri pazarlama literatüründe kabul görmüş kolayda, beğenmeli, özellikli ve aranmayan ürünler şeklindeki ürün sınıflandırmaları bağlamında incelemeyi amaçlamıştır. $\mathrm{Bu}$ sayede gelire ilişkin eşitsizliğe göre tüketim eşitsizliğini incelemek ve sonuçları bu çerçevede yorumlamak daha çarpıcı olacaktır (Keane ve Prasad, 1999). Ayrıca bu çalışmanın tüketim eşitsizliğini ürün sınıflandırmaları çerçevesinde inceleyen ilk çalışma olması açısından ise oldukça özgün bir değer taşıdığı ve ilgili literatüre önemli katkı sağladığı düşünülmektedir.

Çalışmanın bulgularına göre yıllık kullanılabilir gelire ilişkin Gini Katsayısının (0.366), TUİK tarafından açıklanan 2018 yılı eşdeğer hanehalkı kullanılabilir fert gelirine göre Gini Katsayısı (0.408) ile çok yakın değerler taşıyor olması kullanılan veri setinin güvenilirliğine ve temsil gücüne işaret etmektedir. $\mathrm{Bu}$ durumun, çalışmanın özgün değerini arttırdığı düşünülmektedir. Çalışmanın öne çıkan diğer bir bulgusu ise, dört ürün sınıfından seçilen örnek ürünlerin tüketim eşitsizliğini yorumlamaya elverişli bir sonuç ortaya koymasıdır. Buna göre, hemen her profildeki hanehalkı için zorunlu tüketim malları olarak nitelendirilen çay ve yumurta gibi kolayda ürünlere ilişkin eşitsizlik diğer ürün sınıflandırmalarına kıyasla düşüktür. $\mathrm{Bu}$ sonuç, hem beklenen hem de literatür ile örtüşen bir sonuçtur. Idrees ve Ahmad'ın (2010) çalışmalarında da benzer bir sonuç elde edilmiştir. Ayrıca Basole ve Basu'nun (2015) belirttiği gibi, gıda ve gıda-dışı ürünlere ilişkin tüketim eşitsizliğindeki farklılıklar oldukça olağandır. Bununla birlikte, temel gida maddelerinin tüketim miktarının gelir ile çok yakından ilişkisi olduğunu gösteren pek çok çalışmaya paralel olarak bu çalışmada da temel g1da maddelerinde yaşanılan eşitsizlik düzeyi gelir dağılımında mevcut olan eşitsizliğin tam bir yansıması olarak karşımıza çıkmaktadır.
Yine beklenen şekilde, beğenmeli ürün örneklerine ilişkin eşitsizlik katsayısı, kolayda ürünlere göre daha yüksek çıkmıştır. Bunun nedeni ise açık bir biçimde, beğenmeli ürünlerin (bu çalışmada beğenmeli ürünleri temsilen giyim malzemeleri ve ev mobilyası seçilmiştir) çay ve yumurta gibi zorunlu tüketim mallarının aksine hanehalkının yaşamında zorunluluk arz etmemesidir. Dolayısıyla, bu tür ürünlere yapılan değişken ve geniş bir aralıktaki harcamalar söz konusu ürünlerin tüketimlerindeki eşitsizliği arttırmaktadır. $\mathrm{Bu}$ noktada dikkati çeken, giyim malzemelerine göre ev mobilyasına ilişkin eşitsizliğin çok daha fazla oluşudur. $\mathrm{Bu}$ durumu, ev mobilyasında kimi zaman kişiye özel tasarımların tercih edildiği, bu nedenle, bu tür mobilyalara daha fazla harcama yapıldığı varsayımı açıklamaktadır.

Özellikli ürünlere ilişkin elde edilen sonuç incelendiğinde şaşırtıcı biçimde yeni motorlu araçlardaki tüketim eşitsizliği oldukça düşüktür. Ancak ilgili sektördeki yeni araçların fiyat düzeyleri göz önüne alındığında, söz konusu fiyat seviyelerinin birbirine yakın seyretmesi katsayıdaki şaşırtan düşüklüğü aydınlatmaktadır. Özellikli ürünler kapsamında seçilen mücevherat harcamalarındaki yüksek düzeydeki eşitsizlik bu çalışmanın belki de en beklenen sonuçlarından biridir. Bu sonuç ile "tüketimde zorunluluktan uzaklaştıkça eşitsizlik artış eğilimi gösterir” varsayımı bir kez daha doğrulanmış olacaktır. Bununla birlikte, Theil Endeksinin küçük örneklem grubunda daha sağlıklı sonuç vermesi nedeniyle mücevherat harcamalarının eşitsizlik düzeyinin Gini Katsayısından ziyade Theil Endeksi ile değerlendirilmesi daha doğru olacaktır. Bu durum dikkate alındığında, mücevherat harcamasında gözlenen eşitsizlik durumunun daha da fazla olduğunu söylemek yanlış olmayacaktır.

Son olarak, pratikte örneğini bulmanın nispeten daha zor olduğu aranmayan ürünlere ilişkin eşitsizlik katsayıları ortalama olarak özellikli ve beğenmeli ürünlerin altında, kolayda ürünlerin ise yine ortalama olarak üstünde seyretmektedir. Bu çalışmada seçilen özel sağlık sigortası ve cenaze hizmetleri sınıflandırmalarında tüketim eşitsizliği birbirine oldukça yakındır. Bununla birlikte, özel sağlık hizmetlerindeki eşitsizliğe benzer bir bulgu Idrees ve Ahmad'ın (2010) çalışmalarında da öne çıkmaktadır: Söz konusu çalışmaya göre her ne kadar bu çalışmada TÜIKK veri paylaşma biçimi nedeniyle kent-kır ayrımı gözetilmese de kentsel alandaki sağlık harcamaları nispeten daha eşit dağılırken, kırsal alandaki sağlık harcamalarına ilişkin eşitsizlik seviyesi daha yüksek kalmaktadır. Cenaze hizmetlerindeki eşitsizlik durumunun ise, gelir seviyesi yüksek hanehalklarından kaynaklandığı tahmin edilmektedir. Çünkü bilindiği gibi, bazı mezarlıklar ya da cenaze hizmetleri için oldukça yüksek harcamalar yapilabilmektedir.

Araştırmada sunulan bulgulardan yola çıkarak elde edilen sonuçlar çerçevesinde aşağıdaki öneriler getirilmiştir:

- $\mathrm{Bu}$ çalışmada ürün sınıflandırması bağlamında tüketim eşitsizlikleri eşitsizlik ölçümleri yardımıyla incelenmiştir. Çalışmanın devamı olarak ortaya çıkan eşitsizliklerin, hanehalkının sosyo ekonomik özellikleri açısından ekonometrik modellemesi yapılarak eşitsizlik üzerinde etkili olan faktörlerin belirlenmesi sağlanabilir. 
- Eşitsizlik ölçümünün literatürde sıklıkla kullanılan Gini ve Theil katsayıları yardımıyla incelendiği bu çalışma farklı eşitsizlik ölçümlerinin kullanılması ile tekrarlanabilir. Böylece eşitsizlik ölçümleri arasında daha kapsamlı bir karşılaştırma gerçekleştirilebilir.

- Bu çalışmanın sonuçları, piyasa ekonomisinde yer alan aktörler (karar alıcılar) için bir veri kaynağ sağlayabilir. Özellikle ürün sınıflandırması bağlamında elde edilen sonuçlar uyarınca eşitsizliğin düşürülmeye çalışılması ve böylece pazar payının arttırılmasına yönelik kararlar alınabilir.

- Benzer bir araştırma yine TÜİK Hanehalkı Bütçe Anketleri mikro veri setleri yardımıyla boylamsal olarak gerçekleştirilebilir. Böylece zaman içerisinde tüketim eşitsizliğine dair meydana gelen değişimler incelenebilir.

- $\mathrm{Bu}$ çalışmada ürün sınıflarındaki eşitsizlikler seçilen ürün örnekleri özelinde tartışılmıştır. Başka ürün çeşitleri bağlamında tüketim eşitsizliklerinin farklı sonuçlar ortaya çıkarma ihtimalinden nedeniyle gelecek çalışmaların bu noktayı dikkate alarak gerçekleştirilmesi önerilmektedir.

\section{Kaynakça}

Ayyash, M., Sek, S. K. \& Sadeq, T. (2020). Income and Consumption Inequalities in Palestine: a RegressionBased Decomposition Approach. Statistika: Statistics and Economy Journal, 100 (1), 70-86.

Basole, A. \& Basu, D.(2015). Non-Food Expenditures and Consumption Inequality in India. Economic and Political Weekly, 50(36), 43-53.

Blackorby, C., Bosser, W. \& Donaldson, D. (2001). Income Inequality Measurement: the Normative Approach, İçinde: Silber, J. (Ed.), Handbook of income inequality measurement (Vol. 71). Springer Science ve Business Media.

Blundell, R. \& Etheridge, B. (2009). Consumption, Income and Earnings Inequality in Britain. Review of Economic Dynamics, doi:10.1016/j.red.2009.10.004

Chakravarty, S. R. \& Eichhorn, W. (1994). Measurement of income inequality: Observed versus true data. İçinde: Wolfgang Eichhorn (Ed.), Models and measurement of welfare and inequality (ss. 28-32). Berlin: Springer.

Chen, D., Ma, X., Mu, H. \& Li, P. (2010). The inequality of natural resources consumption and its relationship with the social development level based on the ecological footprint and the HDI. Journal of Environmental Assessment Policy and Management, 12(1), 69-86.

Daşkaya, N. \& Sağbaş, İ. (2019). Türkiye'de Tüketim Eşitsizliği: Ampirik Bir Çalışma. Tüketici ve Tüketim Araştırmaları Dergisi, 11(1), 23-42.

Duygan, B. \& Nezih, G. (2006). Income and Consumption Inequality in Turkey: What Role Does Education
Play?. İçinde: S. Altuğ ve A. Filiztekin (Ed.) The Turkish Economy: The Real Economy. Corporate Governance and Reform and Stabilization Policy (ss. 63-91). Londra: Routledge.

Fisunoğlu, H. M., Tekin, İ. \& Laleh, M. M. (2018). Demografik Geçiş ile Gelir ve Tüketim Eşitsizliği İlişkisi: OECD Ülkeleri Üzerine Ampirik Bir Analiz. Hacettepe Üniversitesi Iktisadi ve İdari Bilimler Fakültesi Dergisi, 36(4), 95-115.

Huber, H., Spuhler, T. \& Vogt, A. (1994). The AgeAdjusted Inequality Measure of Gini Used to Measure Inequality in Health Care Costs. İçinde: Wolfgang Eichhorn (Ed.) Models and measurement of welfare and inequality (ss. 100-110). Berlin: Springer.

Idrees, M. \& Ahmad, E. (2010). Measurement and Decomposition of Consumption Inequality in Pakistan. The Lahore Journal of Economics, 15(2), 97-112.

Jacobson, A., Milman, A.D. \& Kammen, D.M. (2005). Letting the (energy) Gini out of the bottle: Lorenz curves of cumulative electricity consumption and Gini coefficients as metrics of energy distribution and equity. Energy Policy, 33(14), 1825-1832.

Kaymak, A. \& Babacan, M. E. (2020). Tüketim Kültürü Bağlamında Türkiye'deki Muhafazakâr Moda Dergileri ve Muhafazakâr Moda Dergilerinin Seküler Moda Dergileriyle Karşılaştırılması Aysha ve Elle Dergileri Örneği. Insan ve Toplum, 10(1), 63-106.

Kavak, B. \& Sı̆̆ındı, T. (2012). Pazarlamadaki Ürün Sınıflandırmasına İlişkin Bir Yazın İncelemesi. Hacettepe Üniversitesi Iktisadi ve İdari Bilimler Fakültesi Dergisi, 30(1), 49-67.

Keane, M. \& Prasad, E. (1999). Consumption and Income Inequality in Poland During the Economic Transition. IMF Working Paper, 99/14.

Kotler, P. (2003). Marketing Management (11th Ed.). New Jersey: Prentice Hall.

Lancaster, G. \& Reynolds, P. (2005). Management of Marketing. New York: Routledge.

Lamb, C. W., Hair, J. F. \& McDaniel, C. (2009). Essentials of Marketing (6th Ed.). South-western Cengage Learning.

Malakar, K. \& Mishra, T. (2017). Application of Gini, Theil and concentration indices for assessing water use inequality. International Journal of Social Economics, 44(10), 1335-1347.

Orhan, A. \& Demir, S. (2019). Gelir Dağılımı Eşitsizliğinin Ölçümünde Gini Katsayısı mı Theil Endeksi mi? II. International Conference on Empirical Economics and Social Sciences, Bandirma Turkey, 1331-1345.

Özdemir, M. Ç. (2019). Özellikli Objektif Gelir Eşitsizliği Ölçüm Yöntemleri Üzerine Değerlendirmeler. İçinde: O. Metin (Ed.) Sakarya Üniversitesi Çalışma Ekonomisi ve Endüstri İlişkileri Seçme Yazllar III (s.35-54). Sakarya: Sakarya Yayıncılık. 
Öztornacı, B. \& Demirdöğen, A. (2015). Farklı Eşdeğerlik Ölçeklerine Göre Temel Yoksulluk Göstergelerinin Değişimi: Türkiye Örneği. Tarım Ekonomisi Dergisi, 21(1 ve 2), 7-15.

Sarangi, P. \& Panda, B. K. (2008). Consumption, Poverty and Inequality (First Edition). New Delhi: Discovery Publishing House.

Xia, Q., Li, S. \& Song, L. (2020). Consumption Inequality in Urban China. İçinde: T. Sicular, S. Li, X. Yue \& H. Sato (Ed.) Changing Trends in China's Ineaquality: Evidence, Analysis and Prospects. Oxford: Oxford University Press.

Tamkoç, M. N. \& Torul, O. (2020). Cross-Sectional Facts for Macroeconomists: Wage, Income and Consumption Inequality in Turkey. The Journal of Economic https://doi.org/10.1007/s10888-019-09436-4

Theodorakis, P.N., Mantzavinis, G.D., Rrumbullaku, L., Lionis, C. \& Trell, E. (2006). Measuring health inequalities in Albania: a focus on the distribution of general practitioners. Human Resources for Health, Vol. 4 5pp., available at:
www.ncbi.nlm.nih.gov/pmc/articles/PMC1395320/ (accessed September 9, 2015).

Todaro, M. P. \& Smith, S. C. (2015). Economic Development (12th ed.). London: Pearson Education Limited.

Torlak, Ö. (2016). Tüketim: Bireysel Eylemin Toplumsal Dönüşümü (2. Bask1). İstanbul: İnkılâb Basım Yayım.

Uysal, S. \& Vatansever Deviren, N. (2016). Küreselleşmenin Gelir Eşitsizliğine Olan Etkisinin Analizinde Yeni Bir Yöntem: Küresel Gelir Dağılımı Endeksi. Uluslararası Sosyal Araştırmalar Dergisi, 9(44), 1250-1259.

Wright, R. (1999). Marketing: Origins, Concepts, Environment (1st Ed.). London: Business Press Thomson Learning.

Zhang, S., Li, F. \& Xiao, J. J. (2020). Internet Penetration and Consumption Inequality in China. International Journal of Consumer Studies, 1-16, DOI: 10.1111/ijcs.12575. 